\title{
Expatriate Satisfaction in International Assignments: Perspectives from Indian IT Professionals Working in the US
}

\author{
Sujoya Ray Moulik \\ Research Scholar, Department of Business Management \\ University of Calcutta, India \\ E-mail: rm_sujoya@ rediffmail.com
}

Dr. Sitanath Mazumdar

Professor \& Formerly Dean, Department of Business Management

University of Calcutta, India

Accepted: July 08, 2012 Published: August 09, 2012

Doi:10.5296/ijhrs.v2i3.2141ＵRL: http://dx.doi.org/10.5296/ijhrs.v2i3.2141

\begin{abstract}
Rapid globalization and boundary less business ventures have contributed to a growing number of expatriates working in foreign locales. As a result of this, it is increasingly important that multinational corporations sending their employees for international assignments prioritise expatriate management. The Global Delivery Model followed by the Indian software firms creates a number of onsite (international) opportunities for Indian software professionals. The effective management of expatriates is increasingly been recognised as a major determinant of success or failure in international business. This study attempts to identify factors that impact expatriate satisfaction in the software industry. Using the method of exploratory factor analysis, through a survey conducted of 75 Indian expatriates currently on assignment in the United States, 25 variables which impact expatriate performance have been grouped into five factors and the correlations of these factors with overall expatriate satisfaction have been examined.
\end{abstract}

Keywords: Expatriation, Indian Software Industry, Job Satisfaction

\section{Introduction}

Internationalisation of business and global outsourcing of services have given rise to 
mammoth opportunities for international exposure for today's workforce. In the context of Information Technology (IT) services, Indian software firms provide IT solutions to organisations all around the globe. Besides generating domestic employment, the need for onsite support (international) has led to a large number of expatriates being sent on international assignments to multiple locations across the globe.

Expatriates play a crucial role for their organization and performance of a company in the international arena is largely reliant on the performance of its expatriate employees (Tung, 1981).Multiple factors have discerning impact upon expatriate assignments and organisations need to respect that simply prioritising international business in terms of revenue would be incomplete without sound expatriate management policies. The human and financial costs of underperformance/failure in the international business area are considerably more severe than in the domestic area. Many organisations relatively new to the international scene underestimate the complex nature of human resource (HR) problems in the international arena and that business failures in the international arena may often be linked to the poor performance of expatriates (Forster, 2000).

\section{Literature Review}

\subsection{Managing the Expatriate Experience: Key Concerns}

Existing literature on international human resource practices suggests that traditional parameters of human resource management may prove insufficient to deal with mobility needs or with the willingness of managers to accept and commit to international transfers. (Schuler et al 1993; Adler and Gunderson,2008; Dowling et al ,2009; Luthans and Doh ,2009) .The whole question of expatriate management in multinational companies involves a complex range of issues and research to date suggests that rigorous performance management systems for expatriates are far from universal. Also, problems in cultural adjustment which may have an impact on work performance should be considered when assessing an expatriate's performance in a new role. Dual career couple issues are another area of concern in managing expatriates. Similarly, when home-country organisations do not value expatriate experience and fail to make positive use of repatriated employees, this can discourage new candidates from accepting expatriate assignments. Expatriation not only contributes to revenue of the organisation but also allows knowledge transfer that could have a positive impact of organisational learning and effectiveness. Thus it is imperative that policies encouraging expatriation, enabling superior performance and enhancing expatriate satisfaction be well crafted and executed.

Much research in the context of expatriation has focused on expatriate management practices ranging from expatriate selection, compensation and re-entry technicalities. Tung (1987) examined expatriate selection practices across 80 U.S. MNCs, and subsequently, identified four general categories which may contribute to expatriate success. These are broadly described as (1) technical competence on the job, (2) personality traits or relational abilities, (3) environmental variables, and (4) family situation. Ronen's (1989) model incorporates the 
dimensions of expatriate success identified by Tung (1981). Ronen (1989) describes five categories of attributes of expatriate success: (1) job factors, (2) relational dimensions, (3) motivational state (4) family situation, and (5) language skills. Over the years subsequent studies have attempted to identify different variables which impact expatriate success .Factors such as family and social tensions, initial cultural shock and adjustment to culture-cum-work environments and reverse culture shock on return have been found to be recurring problems in many companies (Daily et al., 2000; Chew 2004; Caligiuri and Lazarova, 2001; Tung, 1998).

Expatriate failure is a costly problem for any organization. . It is well accepted for an expatriate to be successful he/she should be technically competent and must possess the ability to adapt to the international culture and work environment where he/she is assigned. In the selection process, the expatriate candidate's track record in terms of technical competence is relatively easy to assess from past performance records. However, the expatriate's ability to adapt is more elusive. Avril and Magnini (2007) describe a "holistic approach" to be utilized by multinational corporations to select and train expatriates. Their holistic approach addresses factors such as the expatriate's family situation, the expatriate's diet and exercise habits, his/her emotional intelligence, and his/her learning orientation. In addition, once the expatriate has begun his/her assignment, the home office should continue to show support to the expatriate in the form of adequate compensation, adjusting performance indicators for the foreign setting and through open communication.

\subsection{Expatriate Satisfaction: Dimensions and Determinants}

Expatriate assignments are coveted and accepted for various reasons. Motivations to engage in expatriate assignments vary extensively between individuals and depend largely on personal circumstances. An individual's motivations to go on an international assignment include a number of positive outcomes, including skill acquisition, personal development, long-term career advancement and financial prosperity. Factors including quality of life, work life balance and family stability, all assist in the decision-making process of an international career, future career direction, and later whether to remain in the host country (Crowley-Henry, 2007).

But expatriate assignments do entail multiple dimensions some of which might prove difficult to the employee. Adjustment is pivotal to the success of an expatriate assignment in any location. Success of an expatriate assignment is the result of a successful acclimatisation and adjustment phase, with methods endorsed or provided by their organisation. A gamut of input ranging from pre-departure preparation, on-arrival and continued support all contributed to the perceived success of expatriate assignments.

Naumann (1993) argues that attributing expatriate failure only to employee characteristics may be too simplistic. Organisations should design foreign assignments keeping in mind aspects such as the job/task characteristics (particularly role ambiguity), skill variety, task 
identity, task significance, and autonomy were specifically addressed in the development of foreign job descriptions. This would in turn have a positive impact on expatriate job satisfaction and this could potentially reduce the number of expatriate failures or premature returns from overseas assignments. Providing more clarity, more autonomy, allowing the use of diverse skills, and permitting more significant tasks to be completed may result in a more personally satisfying work experience for the expatriate.

Downes et al (2000) identify three dimensions of expatriate satisfaction. First are the individual - level determinants which would encompass the individual's ability to deal with intercultural stress, communication and relationships. The ability to deal effectively with frustration, stress, different political systems, interactions with strangers and a host of other intercultural dimensions reduce anxiety and increase expatriate satisfaction. Job satisfaction when measured in terms of social aspects, esteem and self-actualisation needs could be higher in the context of international assignments. Ability to adjust with the host environment may have a positive effect on the perceptions towards the assignments per se. The Organisational -level determinants of expatriate satisfaction comprise the different job /task characteristics (skill variety, autonomy, etc) which enhance both intrinsic and extrinsic satisfaction. Skill development opportunities and career development programs linked to the work assignments also play a role in enhancing expatriate satisfaction. Environment-level determinants of expatriate satisfaction are linked to the location of the assignment. Political stability, difference with home country culture and duration of assignment allowed by that region would be moderating factors in this category.

The dynamics of an international assignment obviously vary from a home country assignment in view of the work and national culture differences which translate into differences in the what work is done and overviewed, standards of performance, recognition and rewards, status of employment and other factors. This in turn indicates that the psychological contract for expatriates may vary from traditional psychological contracts. In their study on expatriate psychological contract, Pate and Scullion (2009) point out that the overall tone of the psychological contract from the employers' perspective is transactional. From an employee perspective, preliminary evidence suggested that the dynamics of the employment relationship is changing and that employees have responded to contract changes by seeking to ensure their employability and reduce their dependence on a single organisation. Four action points for managing expatriates have been discussed in their research. First, organisations must pro-actively influence expatriates' expectations thereby minimising misunderstandings; second, organisations should be very aware of "the remuneration market rate" for a particular location; third, policies of support and contact would aid feelings of integration. Finally, more attention should be paid new approaches to strategic talent management. Employers and employees adopt a more transactional relationship in today's society; however, with regards to expatriation, organisations need to look at employees' career needs and how certain factors influence individuals in their career, which should correlate to enhance success and effectiveness of employees (Crowley-Henry, 2007). Studies have corroborated the fact that communication and adjustment were positively correlated to job satisfaction, coping with 
stress and increased support with local work cultures (Kim 2008, Xu 2009)

\subsection{The Indian Software Industry: A Platform for International Exposure}

India's software and services exports have been rising rapidly over the last decade. The growth in this sector is driven by steady increase in scale and depth of existing service lines; addition of newer vertical-specific and emerging niche business services, continued expansion of service portfolios and higher value processes. The IT industry is highly export oriented. Some Indian IT companies have already moved into significantly higher value added segments such as mission- critical applications, development and support, product design, HR management, knowledge process outsourcing for pharmaceutical companies and large complex projects. The rise of the Indian software industry has provided substantial benefits to U.S. firms- both users and developers of software. U.S. firms benefit because Indian software firms compete fiercely among themselves for contracts. As a result, users enjoy most of the gains from trade. They can tap a source that is flexible, cost effective, and willing to work on mundane tasks, freeing up in-house staff for more creative work. (Arora et al 1999). Indian firms provide essential maintenance and development services, enabling US firms to use their scarce in-house IT staff for higher value added work, such as design and develop new types of applications. In doing so, Indian firms often act as sub-contractors to established US software services firms and systems integrators. In addition, many of these U.S. firms rely on Indian programmers and have significant India based operations.

NASSCOM (2012) states that India's Outsourced Software Product Development (OSPD) exports market crossed the billion dollar mark in FY2011.IT services exports is the fastest growing segment, growing by 19 per cent in FY2012, to account for exports of USD 40 billion. In FY2012, OSPD market is expected to grow faster than industry average at 17 per cent to cross USD 1.2 billion in exports. The Global Delivery Model adopted by Indian service providers involves an optimal mix of onsite, offshore and nearshore resources to meet requirements of client organisation. In this model, a team from a tech company evaluates and consults the client requirements at the client location while another team in an offshore location executes the client requirements. In terms of real-time/extended work day, a major benefit derived from this model is that both consultation and execution can take place in real-time as a result of the 10-12 hour time difference between the US and India. Indian companies have been able to create jobs at onsite locations resulting in a large number of expatriate assignments for Indian software professionals.

In their research on the different dimensions of expatriation, Koteshwari and Bhattacharya (2007) discuss at length the expatriation cycle of working overseas and the various potential stressors and challenges employees face when they go to a foreign country to work. These stressors included cultural shock, language barriers, and separation from family. Both individual and organizational strategies can reduce the possibilities of stress among expatriates. At the organizational level, pre- and post departure training, language training, cross-cultural training need to be implemented and they should be regularly monitored. At the individual level, expatriates should be supported by the family and friends. 
Though there seem to be plethora of research on the different dimensions of expatriation per se, studies on Indian expatriates or expatriation experiences of Indian professionals working on foreign assignments seem to be limited. In a study on experiences of Indian expatriates in the United States, Gai et al (2011) studied job satisfaction variables, stress, social support, general health, and psychological well-being of 30 Indian expatriates in the IT sector in the US. Results suggested that these workers tended to have lower satisfaction with aspects of work associated with pay and promotions compared to aspects of work having to do with people (e.g., co-workers, supervisors). These findings were not considered unexpected as pay and promotion opportunities may truly be limited for these workers compared to others in the US working in the same or similar experiences. The range of psychological variables assessed including autonomy, self-acceptance, mastery and growth were marginal in level, suggesting opportunities to improve the psychological functioning of these workers. Stress and psychological well-being, stress and satisfaction, and social support and psychological well-being were found to be related. Socialization and social support among Indian expatriates were identified as important variables particularly as these relate to psychological well-being.

It is imperative that international $\mathrm{HR}$ practices be designed so as to enable expatriate satisfaction which in turn would manifest into the firm's success in the global arena. The following study looks at the factors influencing satisfaction on expatriate assignments from the perspectives of Indian nationals on expatriate assignments in the US.

\section{Objectives Of The Study}

This paper is an attempt to identify and explore the different factors affecting the level of satisfaction with the overall expatriate experience of Indian IT professionals working on international/expatriate assignments in the US. In the course of subsequent discussion, the paper also looks at how international HR policies can organisations can contribute to successful expatriate management

\section{Research Methodology}

\subsection{Designing the Research Instrument:}

Data collection executed through a structured questionnaire consisting 2 segments. Segment 1, the Expatriate Experience (EE) Scale consists 25 items (5 point Likert scale with 1= strongly disagree to $5=$ strongly agree) with a Cronbach's alpha of .929 covering different variables affecting international work assignments ranging from concerns over job, career family, expatriation training to repatriation concerns. These items chosen were based on previous research on expatriation (Naumann 1993; Downes 2000; Koteshwari and Bhattacharya, 2007).

Segment 2 is the Employee Satisfaction (ES) scale consisting items pertaining to job 
satisfaction on expatriate assignments (10 items modeled on the Minnesota Satisfaction Questionnaire, MSQ short form, 1977 version, but customized for the present study).The reliability coefficient (Cronbach's Alpha) for this scale was found to be .898. Respondents were asked to indicate how satisfied they are with respect to each of the statements using a five-point Likert scale ranging from $1=$ extremely dissatisfied to $5=$ extremely satisfied. Respondents were also required to provide demographic information.

\subsection{Sample:}

Using simple random sampling, data was collected from 75 (total sent-125, received 75) Indian IT sector employees (both male and female) with a minimum of 3 years continuous experience on an international assignment. Employees working in NASCOMM listed organisations were chosen for this survey. Of the 75 respondents, 41 were administered the same in person, 21 via e-mail and the remaining 13 telephonically. Most of the 75 respondents were based in the US states of Illinois, New Jersey and Minneapolis. Of the 75 respondents 14 were female the remaining 61 male. The age distribution of the respondents varied from 32 to 45.

\subsection{Survey and Analysis:}

In order to group the variables in distinct areas of importance and their relation to work attitudes and job satisfaction, the data obtained in Segment 1 of the research instrument has been evaluated by exploratory factor analysis in SPSS which yielded 5 factor groups covering different dimensions of expatriate work experiences. The HR implications for these factors have been discussed in relevance to the importance of these factors in expatriate management policies. Subsequently, correlations and regression between the EE factor groups and expatriate satisfaction (measured on the ES scale in Segment 2 of the questionnaire) were explored and are discussed at length in the following sections of this paper.

\section{Findings And Analysis}

\subsection{Reliability and Factor Analysis:}

When tested for the Cronbach's Alpha Co-efficient Reliability Score the Expatriate Experiences scale was found to have a score of .929 and the Job satisfaction Scale score was found to be .898 on the basis of which the study was continued with these two scales.

In the next stage factor analysis for the segment on Expatriate Experiences was found to be possible based on confirmation that the data are correlated revealed by the Kaiser-Meyer-Olkin Measure of Sampling Adequacy (.756) The data was analyzed using factor analysis (Principal Components Method with Varimax Rotation). Table 1 depicts the Rotated Component Matrix for the subsequent factor analysis. Each item of Segment 1 of the questionnaire used for the survey has been has been briefly stated in the same. 
Table 1: Rotated Component Matrix*

\begin{tabular}{|c|c|c|c|c|c|c|}
\hline & & Compc & nent & & & \\
\hline & Item Description (in brief) & 1 & 2 & 3 & 4 & 5 \\
\hline $\mathrm{I} 1$ & $\begin{array}{l}\text { My candidature and willingness to relocate } \\
\text { was discussed with me prior to my selection } \\
\text { for the assignment }\end{array}$ & 0.448 & 0.582 & 0.316 & 0.084 & 0.073 \\
\hline $\mathrm{I} 2$ & $\begin{array}{l}\text { On selection I was clearly briefed of my } \\
\text { responsibilities/job requirements. }\end{array}$ & 0.329 & 0.76 & 0.177 & -0.121 & -0.335 \\
\hline $\mathrm{I} 3$ & My family was supportive of my relocation & 0.296 & 0.223 & 0.259 & 0.658 & -0.003 \\
\hline I4 & $\begin{array}{l}\text { My immediate family have adjusted to the } \\
\text { relocation }\end{array}$ & 0.066 & 0.088 & 0.273 & 0.749 & 0.224 \\
\hline I5 & $\begin{array}{l}\text { My work responsibilities here are similar to } \\
\text { what I have been doing back home }\end{array}$ & 0.467 & 0.439 & 0.349 & 0.253 & 0.135 \\
\hline I6 & $\begin{array}{l}\text { My supervisor back home explained how this } \\
\text { job would positively impact my career }\end{array}$ & 0.05 & 0.573 & 0.146 & 0.391 & 0.543 \\
\hline $\mathrm{I} 7$ & $\begin{array}{l}\text { Pre-departure training including Visa } \\
\text { interview training and cross cultural } \\
\text { differences were provided to me prior to my } \\
\text { assignment. }\end{array}$ & 0.224 & 0.743 & -0.102 & 0.251 & 0.052 \\
\hline I8 & $\begin{array}{l}\text { I have been given ample autonomy to be } \\
\text { accountable for my performance }\end{array}$ & 0.805 & 0.36 & 0.094 & -0.044 & 0.225 \\
\hline I9 & $\begin{array}{l}\text { My role in my assignment is significant in } \\
\text { the project to which I am assigned. }\end{array}$ & 0.847 & 0.211 & 0.119 & 0.075 & 0.046 \\
\hline $\mathrm{I} 10$ & $\begin{array}{l}\text { I am satisfied with the remuneration package } \\
\text { offered to me }\end{array}$ & 0.861 & 0.134 & 0.105 & 0.172 & 0.205 \\
\hline I11 & $\begin{array}{l}\text { My assignment is commensurate with my } \\
\text { qualifications and experience }\end{array}$ & 0.872 & 0.117 & 0.003 & 0.096 & 0.276 \\
\hline $\mathrm{I} 12$ & $\begin{array}{l}\text { I am given adequate opportunity for learning } \\
\text { and development in the course of my } \\
\text { assignment }\end{array}$ & 0.697 & 0.334 & -0.103 & 0.105 & 0.333 \\
\hline I13 & $\begin{array}{l}\text { I can understand my career progression in } \\
\text { relation to my present assignment }\end{array}$ & 0.652 & 0.439 & 0.221 & 0.368 & -0.163 \\
\hline I14 & $\begin{array}{l}\text { My company back home provides ample } \\
\text { opportunity for communication, feedback } \\
\text { and clarifications with my offshore } \\
\text { colleagues/management }\end{array}$ & 0.325 & 0.734 & 0.188 & -0.109 & 0.321 \\
\hline I15 & $\begin{array}{l}\text { My company takes care of my family's } \\
\text { relocation (Visa, tickets, initial housing etc) }\end{array}$ & -0.083 & -0.122 & -0.021 & 0.708 & -0.235 \\
\hline I16 & $\begin{array}{l}\text { On my return, my expatriate experiences } \\
\text { shall contribute to my growth in the company } \\
\text { back home }\end{array}$ & 0.376 & 0.046 & 0.143 & 0.088 & 0.854 \\
\hline I17 & $\begin{array}{l}\text { My friends and family believe my } \\
\text { assignment is a positive event in my life }\end{array}$ & 0.492 & 0.166 & 0.273 & 0.512 & 0.297 \\
\hline I18 & $\begin{array}{l}\text { I shall be considered for future opportunities } \\
\text { if I perform well in this assignment }\end{array}$ & 0.038 & 0.204 & -0.648 & 0.194 & 0.485 \\
\hline I19 & $\begin{array}{l}\text { I have no difficulty communicating (verbal } \\
\text { and non verbal) with my work group. }\end{array}$ & 0.092 & 0.243 & 0.685 & 0.319 & 0.245 \\
\hline
\end{tabular}




\begin{tabular}{|l|l|l|l|l|l|l|}
\hline I20 & $\begin{array}{l}\text { I am at ease socialising with my colleagues } \\
\text { and social groups in this country } \\
\text { activities, entertainment and culinary } \\
\text { experiences) }\end{array}$ & 0.161 & 0.028 & 0.691 & 0.444 & -0.025 \\
\hline I21 & $\begin{array}{l}\text { I am well adjusted to the work culture in my } \\
\text { onsite assignment }\end{array}$ & -0.124 & 0.017 & 0.729 & 0.284 & 0.252 \\
\hline I22 & $\begin{array}{l}\text { I am given due vacation adjustments to visit } \\
\text { home. }\end{array}$ & 0.283 & 0.107 & -0.066 & 0.716 & 0.441 \\
\hline I23 & $\begin{array}{l}\text { I am free to exercise my culture and beliefs in } \\
\text { the country of my assignment (festivals, } \\
\text { ethnic group activities, socialising etc) }\end{array}$ & 0.461 & 0.327 & 0.573 & 0.031 & 0.308 \\
\hline I24 & $\begin{array}{l}\text { My return to India shall be smoothly } \\
\text { managed ( Visa issues, lease formalities and } \\
\text { lead time) }\end{array}$ & 0.386 & -0.047 & 0.186 & -0.055 & 0.841 \\
\hline I25 & $\begin{array}{l}\text { The work environment/performance } \\
\text { parameters here are similar to that offshore. }\end{array}$ & 0.299 & 0.367 & 0.665 & -0.171 & 0.01 \\
\hline
\end{tabular}

*Extraction Method: Principal Component Analysis; Rotation Method:

Varimax with Kaiser Normalization; Rotation converged in 9 iterations.

Factor Analysis reduced the 25 variables into 5 factor groups. The items with highest loadings were used in assigning the labeling of the factor. Items 5 and 18 both with highest loadings with values less than .5 have been ignored. As per the results of Factor Analysis, the first five factors were chosen because they explained a high proportion of original variance and had Eigen value higher than one. Table 2 summarizes these findings.

Table 2:Total Variance Explained

\begin{tabular}{|c|c|c|c|c|c|c|c|c|c|}
\hline \multirow[b]{2}{*}{$\begin{array}{l}\text { Co } \\
\text { mp } \\
\text { one } \\
\text { nt }\end{array} \mid$} & \multicolumn{3}{|c|}{ Initial Eigen values } & \multicolumn{3}{|c|}{$\begin{array}{l}\text { Extraction Sums of } \\
\text { Squared Loadings }\end{array}$} & \multicolumn{3}{|c|}{$\begin{array}{l}\text { Rotation Sums of Squared } \\
\text { Loadings }\end{array}$} \\
\hline & Total & $\mid \begin{array}{l}\% \text { of } \\
\text { Varianc } \\
\mathrm{e}\end{array}$ & $\begin{array}{l}\text { Cumulative } \\
\%\end{array}$ & Total & $\begin{array}{l}\% \text { of } \\
\text { Varianc }\end{array}$ & $\begin{array}{l}\text { Cumulati } \\
\text { ve } \%\end{array}$ & Total & $\mid \begin{array}{l}\% \text { of } \\
\text { Varianc } \\
\text { e }\end{array}$ & $\begin{array}{l}\text { Cumulativ } \\
\text { e \% }\end{array}$ \\
\hline 1 & 10.056 & 40.224 & 40.224 & $\begin{array}{l}10.05 \\
6\end{array}$ & 40.224 & 40.224 & 5.527 & 22.108 & 22.108 \\
\hline 2 & 2.892 & 11.568 & 51.791 & 2.892 & 11.568 & 51.791 & 3.496 & 13.985 & 36.093 \\
\hline 3 & 2.552 & 10.208 & 61.999 & 2.552 & 10.208 & 61.999 & 3.358 & 13.432 & 49.525 \\
\hline 4 & 1.869 & 7.475 & 69.474 & 1.869 & 7.475 & 69.474 & 3.234 & 12.938 & 62.462 \\
\hline 5 & 1.371 & 5.485 & 74.959 & 1.371 & 5.485 & 74.959 & 3.124 & 12.497 & 74.959 \\
\hline
\end{tabular}

Extraction Method: Principal Component $f$

\subsubsection{Interpretation of Factors and Implications for International Human Resource (HR) Practices}




\section{Factor 1: Work and Career Issues}

This factor comprises issues pertaining to the job per se, clarity and congruence of the role to expectations and experience, autonomy, learning and growth opportunities as well as reward and recognition issues.

Research suggests that if international assignments were designed keeping in mind the different aspects of job design principles such as particularly role ambiguity, skill variety, task identity, task significance, and autonomy expatriate job satisfaction may increase. It has also been observed that Expatriates who perceive career benefits resulting from their international experience tend to be more satisfied. This would suggest that those organisations that identify a specific career track flowing from a foreign assignment will have a more satisfied expatriate work force. (Naumann, 1993). Studies have reported that expatriates receive significant personal and self-development benefits from foreign assignments. They gain a broader, global perspective on the firm's operations. Their communication skills are enhanced because of their exposure to different cultures. The more complex the environment, the more it enhances their planning and motivation techniques, thus, confidence increases. These types of development can have positive career and organizational implications. It is desired that HR managers devise practices to better manage this critical resource (the expatriates) in order to maximize the wealth of knowledge and experience gained from international assignments. Performance development and management practices would have to be designed in such a way so as to capture the best of development opportunities. (Webb 1996; Fenwick 2004).It has been seen that expatriates demonstrate a high commitment to the international element of their careers and to its value as a means of securing organisational success into the future. (Suutari, 2003). Bonache (2005) in a study comparing satisfaction of expatriates of both domestic employees and repatriates found that expatriates are in general more satisfied with a number of job characteristics. Specifically, they value more positively the extent to which their jobs have task variety and autonomy, provide opportunities for learning, allow them to apply their knowledge and give them enough responsibility. These findings lend support to authors such as Suutari (2003) who claim that the best part of international assignments is related to the new work experiences and learning they offer.

\section{Factor 2: Pre assignment Preparedness:}

This factor group comprises the effective pre expatriation selection, training and socialization methods employed by parent organisations. It is imperative that not just technical considerations but also an employee's willingness and motivation to relocate, albeit temporarily, are not ignored. Cross cultural training initiatives, realistic job previews and subsequent socialization practices are of pivotal importance in this regard. Given that IT projects cover a large range of technical knowhow (and roles ranging from developers, analysts, system architectures and managers) selecting the right person for the right project is important. Previous exposure to that technology and similar projects is imperative selection criteria and only those fulfilling this criteria paired with willingness to relocate should be 
presented to the client for selection. Visa formalities in terms of training for Visa interviews is also an important dimension in this area as there have been incidents of Visa rejections on account of poor ability to communicate the grounds of being sent on an international assignment during the one-to -one interviews.

Shih, Chiang and Kim, (2005) reported that most organisations do not provide on-the-job training for expatriates on their overseas missions. This may be because some expatriates are at the management level, and their companies find less need for these managers to receive on-the-job training. On the other hand, the lack of on-the-job training may be because the organisation lacks a comprehensive plan for capitalizing on their global management capital. According to Coyle (1996), once an employee has previous overseas experience, and is classified as a career expatriate, there is a tendency for companies to minimize the material and counseling support given before and after the move. Black and Gregersen (1991) argued that the extent of previous experience does not necessarily seem to ensure success in current overseas assignment. In the context of preparing the selected expatriate for the assignment Luthans and Farner, (2002) propose a multisource or 360-degree feedback technique as an effective tool for evaluating various levels of expatriate training, to ensure the previous questions are being addressed. The strength of this approach is that it helps to gather information from various sources in order to understand what behavioral changes and on-the-job performance improvements have resulted from the cultural training program.

\section{Factor 3: Acculturation and Adjustment}

This factor group addresses the issues pertaining to cross cultural adjustment both in the workplace and in daily life. Feelings of stress in a new work environment, ability to decode the communication (verbal and non -verbal) and social etiquette and acclimatizing oneself with the way work is done in terms of interpersonal and team protocols comprise this set of factors which impact satisfaction an expatriate feels while on assignment.

Expatriate adjustment has been commonly defined as "the degree of comfort or absence of stress associated with being an expatriate" (Bhaskar-Shrinivas, Harrison, Shaffer, \& Luk, 2005) Black, Mendenhall \& Oddou (1991) provide a framework for the three different levels of adjustment expatriates experience. General adjustment is the degree of comfort with living conditions, climate, food, housing and cost of living. Interaction adjustment is the individual's comfort at socialising and interacting with host nationals. The third dimension is adjustment to work, which includes understanding and adapting to foreign specific work duties, responsibilities, standards and expectations. Expatriates reach a level of comfort when all levels of adjustment have been satisfied. Studies have revealed several factors associated with expatriates' improved sociocultural adjustment, such as psychological hardiness (White, Absher, \& Huggins, 2011) and perceived distance between the expatriate's native culture and the host culture (Jenkins \& Mockaitis, 2010). In this context, the role of the extent and nature of support from the employees' own organisation cannot be ignored. Close contact with the newly assigned expatriates and continuous monitoring of events may provide a basis for assessing their emerging support needs. (Selmer, Chiu and Shenkar, 2007).It is important that 
expatriates need to be more tolerant and optimistic in their attitudes towards cultural differences that occur in a cross-cultural environment. (Tahir and Ishmail, 2007) It has been observed that both cross-cultural training and the language spoken in the host country affect the accuracy of expatriates' expectations prior to the assignment - and that having accurate expectations, in turn, positively affects cross-cultural adjustment .(Caligiuri et al,2001)

\section{Factor 4: Family Concerns}

This group of variables encompass spousal and family attitudes towards expatriation, relocating to a new country, dual career issues and willingness to support the expatriate (long distance or otherwise).

Research suggests that one of the key causes for the premature return of expatriates from overseas assignments was related to concerns that were articulated as family reasons. This evidence supports previous studies on expatriate failure indicating the inability of the spouse to adapt to the foreign environment as the frequent cause of the early return of the expatriate (Tung 1987, Forster 2000). A major challenge for the human resource profession lies in developing institutional mechanisms that heighten priority on family adaptability in their selection criteria. A related issue in this context is the dual career dilemma was which can affect career development plans for international employees. Most companies recognised the issue of the dual career couple, but are still unsure how to manage the problem in relevant HRM policies and practices. (Chew, 2004) For employees with children, the difficulty of adapting to new schools, new friends, and the like, children often must also learn a new language, new culture, new replacement sports and hobbies, and so on.

Programs could include cross-cultural and language training, relocation assistance, and so on. Although cross-cultural and language training are commonly offered to the expatriate, organizations could demonstrate their support for expatriate families by offering such training to the spouse and children .Improving a family's cross-cultural adjustment could in turn improve an expatriate's job performance while on the global assignment .Caligiuri et al (1998) point out that the assignment could affect children's or spouses' education, or could also result in a spouse abandoning his or her career, leading to similar issues of stress and discontent .

There are certain organizational programs that can be extended to the spouses and children of expatriates prior to departure. Ongoing support once the family is on the assignment also would be beneficial. Such in-country support could include an orientation program, mentoring, job placement assistance for the spouse, and social support from the organization .Providing supports for the family on a global assignment helps them re-establish a social network. This is important because the family's ability to re establish support systems affects the outcome of the global assignment

\section{Factor 5: Repatriation Concerns}

In this study all respondents are aware of the fact that these international assignments are 
not permanent relocations and at one point they will have return to their parent organisation back home. In this context, it is important that the expatriates are given ample notice and opportunity for a phased transition to deal with the reverse culture shock that they may face after being on international assignment for a prolonged period. Issues pertaining to organisational attitude towards extensions / renewal of work Visas, rotation of employees on international projects (which shorten assignment durations for individuals) and abrupt departures and transitions and opportunities of growth post repatriation and comprise this factor. Repatriation concerns are largely based on how expatriates perceive their colleagues (past expatriates) experiences post repatriation.

Adjusting to repatriation is often more difficult than adjusting to life overseas, as the repatriate may have great aspirations on the career front as a result of acquiring global exposure, skills and experience. Another issue in this context is how the assignment came to an end. Often Visas are not renewed timely due to which expatriates are forced to leave abruptly. Also strategic policy changes in the client organisations may have an impact on tenure and nature of the assignment. Compounded to this, is that on repatriation they have lost most of the generous financial benefits of the expatriate assignment, and because there are often no plans for repositioning them within their organization, they are made to feel as if their assignment was of little or no value to management. They might be expected to resume their earlier roles because management does not know how to use their expertise. Expatriate assignments, which many believe will increase career mobility, can actually slow down promotions. (Webb, 1996) Hyder and Lovblad (2007) claim that repatriation experience is dependent on two main factors: how the reality of the repatriation process meets the expectations of the repatriate; and the impact of demographic factors and cultural identity changes.

Human resource professionals should conduct exit interviews with expatriates and their families on their return home. There is an abundance of practical knowledge and applications to be learned during an expatriate assignment that can be useful to future expatriate workers. Some issues on re-entry include xenophobic attitudes of colleagues and managers at home, underutilization of global managers, unplanned transition and career paths. Organisations should reflect on are how they might help expatriates manage the re-entry transition and make a returnee's transition as easy as possible for the repatriate and as beneficial as possible for the company. (Adler and Gunderson, 2008)

\subsubsection{Factor Scale Analysis Findings}

Internal consistency analysis was carried out to measure the reliability of the items under each factor group using Cronbach's alpha. The alpha scores of each factor scale are given in Table 3. 
TABLE 3: Reliability Statistics for Factor Groups of Expatriate Experiences (EE) Scale

\begin{tabular}{|l|l|l|}
\hline Factor & Factor Title & Cronbach's Alpha \\
\hline 1 & Job Considerations \& Career Growth & .933 \\
\hline 2 & Pre assignment Preparedness & .832 \\
\hline 3 & Acculturation and Adjustment & .834 \\
\hline 4 & Family Issues & .802 \\
\hline 5 & Repatriation Concerns & .941 \\
\hline
\end{tabular}

\subsection{Correlation Analysis:}

For each of the Factor scales the descriptive statistics were determined following correlation analysis between each of the factors and Job satisfaction scores as collected in segment 2 of the research study. The mean scale scores for all 6 scales (5 EE scales and the ES scale) were used in the analysis. The results are tabulated below.

Table 4: Descriptive Statistics for Correlation study

\begin{tabular}{|l|l|l|l|}
\hline Factor Group & Mean & Std. Deviation & N \\
\hline Job Considerations \& Career Growth & 3.596 & 1.0676 & 75 \\
\hline Pre assignment Preparedness & 2.98 & 0.959 & 75 \\
\hline Acculturation and Adjustment & 2.78 & 1.011 & 75 \\
\hline Family Issues & 3.3 & 0.882 & 75 \\
\hline Repatriation Concerns & 3.67 & 1.123 & 75 \\
\hline Expatriate Satisfaction & 3.77 & 0.509 & 75 \\
\hline
\end{tabular}

Table 5: Correlation coefficients between Expatriate Experience Factors and Satisfaction

\begin{tabular}{|c|c|c|c|c|c|c|c|c|}
\hline & & & 1 & 2 & 3 & 4 & 5 & 6 \\
\hline \multirow[t]{3}{*}{1} & \multirow[t]{3}{*}{$\begin{array}{c}\text { Job Considerations } \\
\text { \& Career Growth }\end{array}$} & $\begin{array}{l}\text { Pearson } \\
\text { Correlation } \\
\end{array}$ & 1 & $\begin{array}{l}.661 * \\
* \\
\end{array}$ & $\begin{array}{l}.437 * \\
* \\
\end{array}$ & $\begin{array}{l}.404 * \\
* \\
\end{array}$ & $\begin{array}{l}.514 * \\
* \\
\end{array}$ & $\begin{array}{l}.727 * \\
*\end{array}$ \\
\hline & & Sig. (2-tailed) & & 0 & 0 & 0 & 0 & 0 \\
\hline & & $\mathrm{N}$ & 75 & 75 & 75 & 75 & 75 & 75 \\
\hline \multirow[t]{3}{*}{2} & \multirow{3}{*}{$\begin{array}{c}\text { Pre assignment } \\
\text { Preparedness }\end{array}$} & $\begin{array}{l}\text { Pearson } \\
\text { Correlation } \\
\end{array}$ & $\begin{array}{l}.661 * \\
* \\
\end{array}$ & 1 & $\begin{array}{l}.530 * \\
* \\
\end{array}$ & $\begin{array}{l}.374 * \\
* \\
\end{array}$ & $\begin{array}{l}.333 * \\
* \\
\end{array}$ & $\begin{array}{l}.562 * \\
* \\
\end{array}$ \\
\hline & & Sig. (2-tailed) & 0 & & 0 & 0.001 & 0.004 & 0 \\
\hline & & $\mathrm{N}$ & 75 & 75 & 75 & 75 & 75 & 75 \\
\hline 3 & & $\begin{array}{l}\text { Pearson } \\
\text { Correlation }\end{array}$ & $\begin{array}{l}.437 * \\
*\end{array}$ & $\begin{array}{l}.530 * \\
*\end{array}$ & 1 & $\begin{array}{l}.665 * \\
*\end{array}$ & $\begin{array}{l}.399 * \\
*\end{array}$ & $\begin{array}{l}.530 * \\
*\end{array}$ \\
\hline
\end{tabular}




\begin{tabular}{|c|c|c|c|c|c|c|c|c|}
\hline & \multirow{2}{*}{$\begin{array}{l}\text { Acculturation } \\
\text { and Adjustment }\end{array}$} & Sig. (2-tailed) & 0 & 0 & & 0 & 0 & 0 \\
\hline & & $\mathrm{N}$ & 75 & 75 & 75 & 75 & 75 & 75 \\
\hline \multirow[t]{3}{*}{4} & \multirow{3}{*}{ Family Issues } & $\begin{array}{l}\text { Pearson } \\
\text { Correlation }\end{array}$ & $\begin{array}{l}.404 * \\
*\end{array}$ & $\begin{array}{l}.374 * \\
*\end{array}$ & $\begin{array}{l}.665 * \\
*\end{array}$ & 1 & $.283^{*}$ & $\begin{array}{l}.475 * \\
*\end{array}$ \\
\hline & & Sig. (2-tailed) & 0 & 0.001 & 0 & & 0.014 & 0 \\
\hline & & $\mathrm{N}$ & 75 & 75 & 75 & 75 & 75 & 75 \\
\hline \multirow[t]{3}{*}{5} & \multirow{3}{*}{$\begin{array}{l}\text { Repatriation } \\
\text { Concerns }\end{array}$} & \begin{tabular}{|l|} 
Pearson \\
Correlation \\
\end{tabular} & $\begin{array}{l}514^{*} \\
* \\
\end{array}$ & $\begin{array}{l}333 * \\
* \\
\end{array}$ & $\begin{array}{l}.399 * \\
* \\
\end{array}$ & $.283^{*}$ & 1 & $\begin{array}{l}.603 * \\
* \\
\end{array}$ \\
\hline & & Sig. (2-tailed) & 0 & 0.004 & 0 & 0.014 & & 0 \\
\hline & & $\mathrm{N}$ & 75 & 75 & 75 & 75 & 75 & 75 \\
\hline \multirow[t]{3}{*}{6} & \multirow[t]{3}{*}{$\begin{array}{l}\text { Employee } \\
\text { Satisfaction }\end{array}$} & $\begin{array}{l}\text { Pearson } \\
\text { Correlation }\end{array}$ & $\begin{array}{l}.727 * \\
*\end{array}$ & $\begin{array}{l}.562 * \\
*\end{array}$ & $\begin{array}{l}.530 * \\
*\end{array}$ & $\begin{array}{l}.475^{*} \\
*\end{array}$ & $\begin{array}{l}.603 * \\
*\end{array}$ & 1 \\
\hline & & Sig. (2-tailed) & 0 & 0 & 0 & 0 & 0 & \\
\hline & & $\mathrm{N}$ & 75 & 75 & 75 & 75 & 75 & 75 \\
\hline
\end{tabular}

$* *$. Correlation is significant at the 0.01 level (2-tailed).

*. Correlation is significant at the 0.05 level (2-tailed).

The correlation for mean scale scores shown in Table 4 indicates that the experience factors are positively correlated with expatriate satisfaction. Job Considerations \& Career Growth ( $\mathrm{r}$ $=0.727, \mathrm{p}<0.01)$ is found to have a strong positive correlation with Expatriate Satisfaction. The remaining factors Pre assignment Preparedness $(r=.562, \mathrm{p}<0.01)$, Acculturation and Adjustment $(\mathrm{r}=.530, \mathrm{p}<0.01)$, Family Issues $(\mathrm{r}=.475, \mathrm{p}<0.01)$ and Repatriation Concerns $(\mathrm{r}$ $=.603, \mathrm{p}<0.01)$ have moderate and positive correlations with expatriate satisfaction.

\subsection{Regression Analysis}

The multiple $\mathrm{R}$ value of 0.801 indicates a significant positive relationship between the variables and the adjusted $\mathrm{R}$ squared (0.616) suggests that the Expatriate Experiences factors account for $61.6 \%$ percent of the variance in Expatriate Satisfaction ( $F=24.734$; $p$ < 0.000). Table 6 and table 7 summarizes these findings. (Factor Groups are indicated by their serial number as in Table 3)

Table 6: Model Summary

\begin{tabular}{|l|l|l|l|l|}
\hline Model & $\mathrm{R}$ & $\mathrm{R}$ Square & Adjusted R Square & Std. Error of the Estimate \\
\hline 1 & $.801^{\mathrm{a}}$ & .642 & .616 & .315 \\
\hline
\end{tabular}

a. Predictors: (Constant), Factor5, Factor4, Factor2, Factor1, Factor3

Table 7 :ANOVA ${ }^{\text {b }}$

\begin{tabular}{|l|l|l|l|l|l|l|}
\hline \multicolumn{2}{|l|}{ Model } & Sum of Squares & df & Mean Square & F & Sig. \\
\hline 1 & Regression & 12.293 & 5 & 2.459 & 24.734 & $.000^{\mathrm{a}}$ \\
\hline
\end{tabular}




\begin{tabular}{|l|l|l|l|l|l|l|}
\hline \hline Residual & 6.859 & 69 & .099 & & \\
Total & 19.151 & 74 & & & \\
\hline
\end{tabular}

a. Predictors: (Constant), Factor5, Factor4, Factor2, Factor1, Factor3

b. Dependent Variable: ES

Table 8 : Coefficients ${ }^{\mathrm{a}}$

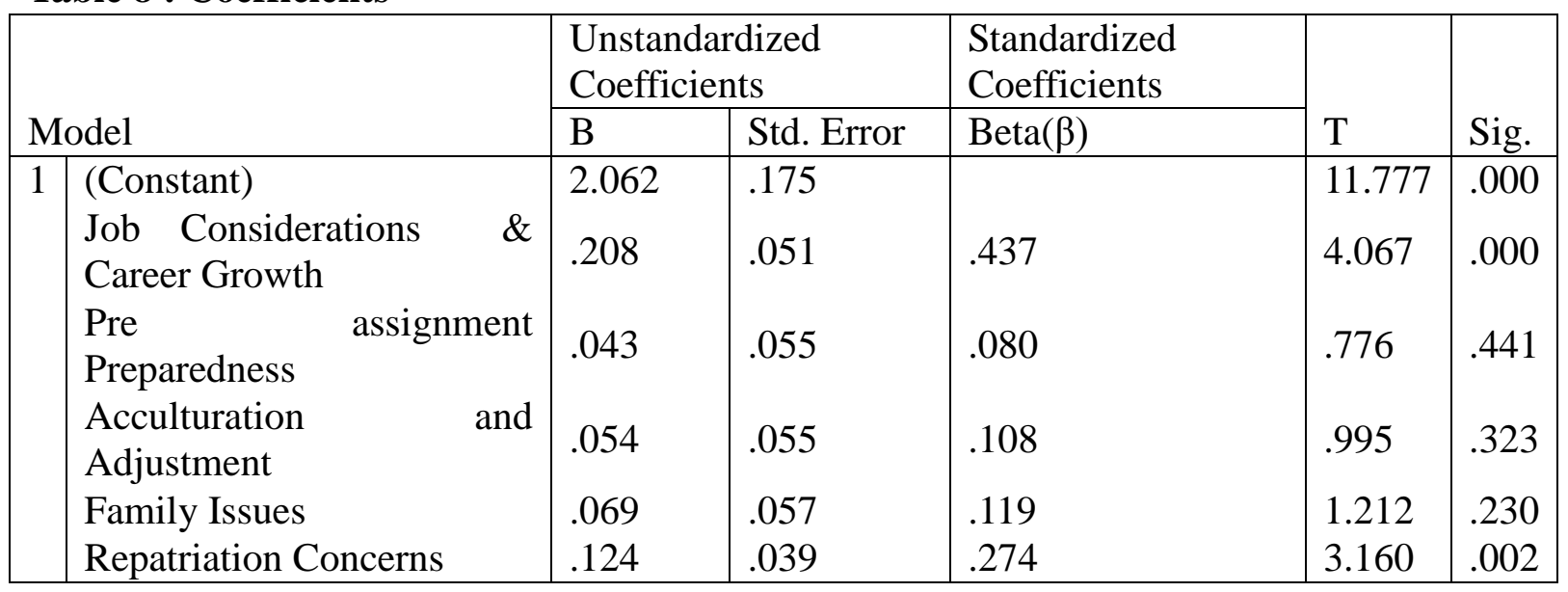

a. Dependent Variable: Expatriate Satisfaction (ES)

The standardized beta estimates (refer Table 8: Factors groups are labeled as in Table 3) were significantly greater than zero for Job Considerations and Career growth $(\beta=0.437, p<0.05)$ and Repatriation Concerns $\quad(\beta=0.274, p<0.05)$. The statistical results demonstrate support for the fact that both these factors have a significant positive relationship with Expatriate Satisfaction (ES).However despite positive correlations in the correlation analysis, the regression model does not lend support for the relationships between the other three EE factors and Expatriate Satisfaction.

\section{Conclusion}

There exists limited research on Indian expatriate experiences on international assignments .This paper proposed and tested the how the different dimensions of expatriate experience are linked to employee satisfaction of Indian expatriate assignments (IT professionals) in the United States. The different dimensions of expatriate experience were derived from existing literature and studies focusing on these dimensions. Indian IT professionals were surveyed on their experiences while on assignment and factors such as Job Considerations \& Career Growth, Pre assignment Preparedness, Acculturation and Adjustment, Family Issues and Organisational Attitude towards Repatriation were identified through exploratory factor analysis.

The general issues addressed in this study are what factors lead to satisfaction (or dissatisfaction) among expatriates and what multinationals can do to enhance their employees' commitment to their jobs and assignments. A common theme that underlies all factors derived in the study is the need for continued support from the individual's own organisation. From efficient selection procedures (person-job and person-culture fit), 
pre-departure training and orientation, career advancement opportunities and re induction upon return- a gamut of responsibility lies with the organisations sending these professionals on assignments. This reinforces the previous research on expatriation concerns (Tung 1987; Naumann, 1993; Yavas and Bodur, 1999; Avril and Magnini 2007; Olsen and Martin, 2009, Tornikowski, 2011)

The results of the correlation analysis support the link between expatriate satisfaction and the dimensions identified in factor analysis. Further, regression analysis results suggest a significant positive relationship exists between two of the five different dimensions of expatriation experiences and expatriate satisfaction. The significant positive correlation between Expatriate Satisfaction and Job Considerations \& Career Growth $(\mathrm{r}=0.727, \mathrm{p}<$ $0.01 ; \beta=0.437, \mathrm{p}<0.05)$ and suggests that employees' whose career aspirations needs are satisfied by an organization would likely be more committed to the assignment. IT professionals form a large chunk of the total knowledge workers working globally- their motivations are largely guided by their perceptions of organisational support, both intrinsically challenging jobs and a certain degree of self management on the job. This in turn implies that HR professionals need to chart out tangible career paths, devise efficient performance management systems and challenging job designs so as to motivate expatriate satisfaction and performance.( Webb,1999;Morgan ,Nie and Young 2004). An interesting observation in this study reveals that IT professionals are happier working onsite ( international) than having to cope with the 12 hour time difference had they been working on the same project back home in the regular offshore outsourcing mode (domestic offshore support/development).

Organisations need to pay attention to perceived Repatriation Concerns $(r=.603, p<0.01 ; \beta$ $=0.274, \mathrm{p}<0.05$ ) so as to ensure that the individual does not perceive repatriation to be a detriment to career development. Lee and Liu (2007) in their study on repatriation adjustment and intention to leave the organisation among Taiwanese expatriates found that expatriates who perceived a higher level of repatriation adjustment had a lower intent to leave the organisation post repatriation. Organisations need to be proactive about re-absorption of returnees and subsequent advancement so as to create positive perceptions in the minds of those working on international. Research suggests that in repatriation programming, a focus on career management is an important intervention to support personal and work adjustment. Repatriation programs need to encourage and train employees to practice proactive career planning behaviors such as taking inventory of the skills developed during their international assignment setting goals based on how they want to utilize these competencies in their home country environment. (Mac Donald and Arthur, 2005)

It is interesting to note that the regression model not lend support to the importance of Pre assignment Preparation $(\mathrm{r}=.562, \mathrm{p}<0.01)$, Acculturation and Adjustment $(\mathrm{r}=.530, \mathrm{p}<0.01)$, and Family Issues $(r=.475, \mathrm{p}<0.01)$ as predictors of Expatriate Satisfaction. In this context it might be pointed out that the present study is based on expatriates based in the US. Given the modern education systems stressing on English medium education in India, global 
management practices in Indian IT firms, exposure to global media in all aspects of life and global influences in urban lifestyle renders living in the US no longer a daunting experience. Western cultures and lifestyles are no longer an unknown force to be dealt with for Indian professionals .Also the growing presence of Indian professionals living and working in the US enable expatriates to maintain a semblance of their own ethnic lives in terms of social life, festivals and entertainment even in while functioning within a different culture .This familiarity or lack of 'newness' may reduce both the initial culture -shock and subsequent adjustment anxiety in Indian expatriates in the US, thereby justifying these findings. This is in support of research looking at degree of perceived differences between host and home country cultures leading to improved socio cultural adjustment (Jenkins and Mockaitis, 2008).

\section{Scope for Further Research}

This paper is based on primary data collected from a relatively small sample of IT professionals working in the US. Also this study is limited to expatriates working in the US. Given that culture, immigration rules and other factors relating to expatriate experiences would differ between different countries of assignment, the EE factors identified in this study may not be universally applicable to all expatriates across nations. Research could be extended to expatriate experiences in different international locations and across different sectors. This research study has targeted individuals who are currently on and have been on assignment for a minimum of three years thus limiting the data collected to experienced individuals. Thus, similar research could be conducted for those who are new expatriates still in their initial socialization stages. Scope also exists for delving into repatriate experiences and how expatriates are re-absorbed into their original workplace.

Despite the limitations of this study, this study does give human resource professionals an idea of what focus points should be looked at while designing jobs and related HR practices for expatriates so as to minimize expatriate failure thereby having a positive impact on profitability and organisational success.

\section{REFERENCES:}

Adler, N.J. and Gunderson A., (2008) International Dimensions of Organizational Behavior, 5 ed., Mason-Ohio, South-Western College Pub

Avril, Alizee B. and Magnini, Vincent P., (2007) A holistic approach to expatriate success. International Journal of Contemporary Hospitality Management, Vol. 19 No. 1, pp. 53-64

Bhaskar-Shrinivas, P., Harrison, D. A., Shaffer, M. A., \& Luk, D. M. (2005). Input-based and time-based models of international adjustment: Meta-analytic evidence and theoretical extensions, Academy of Management Journal, 48(2), pp.257-281.

Black, J.S. and Gregersen, H.B. (1991), The other half of the picture: antecedents of spouse cultural adjustment. Journal of International Business Studies, Vol. 22 No. 3, pp 461-77.

Black, J.S. and Mendenhall, M. (1991), The U-curve adjustment hypothesis revisited: a review and theoretical framework. Journal of International Business Studies, Vol. 22 No. 2, 
pp. $225-247$

Black, J.S. and Stephens, G.K. (1989), The influence of the spouse on American expatriate adjustment in overseas assignments. Journal of Management, Vol. 15, pp. 529-44.

Black, J.S., Mendenhall, M. and Oddou, G. (1991), Toward a comprehensive model of international adjustment: an integration of multiple theoretical perspectives. Academy of Management Review, Vol. 16 No. 2, pp. 291-317.

Bonache, J.(2005),Job satisfaction among expatriates, repatriates and domestic employees: The perceived impact of international assignments on work-related variables, Personnel Review, Volume 34, Number 1, pp. 110-124

Caligiuri, P., Phillips, J., Lazarova, M., Tarique, I., \& Bürgi, P. (2001). The theory of met expectations applied to expatriate adjustment: The role of cross cultural training. International Journal of Human Resource Management, 12(3), 357-372.

Chew, J., (2004),Managing MNC Expatriates through Crises: A Challenge for International Human Resource Management. Research and Practice in Human Resource Management, volume 12, Number 2, pp: 1-30.

Coyle, W. (1996). Career expatriates become global troubleshooters. Human Resource Monthly, 5(6), 24

Crowley Henry. M., (2007) The Protean Career: Exemplified by First World foreign residents in Western Europe? International Studies of Management and Organisation 37 (3)pp 44-64 Dowling, P., Festing, M. and Engle, A. (2009). International human resource management, (5th Ed.). Mason, OH: South-Western Cengage Learning.

Downes M., Thomas, Anisya S., Singley, Rodger B., (2002), Predicting expatriate job satisfaction: the role of firm internationalization. Career Development International, Vol. 7: 1 pp. $24-36$

Fenwick, M. (2004), On International Assignment: Is expatriation the only way to go? Asia Pacific Journal of Human Resources, 42 (3), 365-377.

Forster, N. (2000). Expatriates and the impact of cross cultural training. Human Resource Management Journal, 10(3), 63-78.

Gai S. Sumner K., Bragger J., Nooner, K. (2011) Understanding experiences of Indian expatriates in the United States: stress, satisfaction, social support, and general health. International Journal of Strategic Management, Vol.11, no.3, Pp.158 (9)

Hyder Akmal S., Lövblad M., (2007), The repatriation process - a realistic approach. Career Development International, Vol.12 Iss: 3 pp. 264 - 281

Hsi-An Shih, Yun-Hwa Chiang, In-Sook Kim, (2005)Expatriate performance management from MNEs of different national origins. International Journal of Manpower, Vol. 26 Iss: 2 pp. $157-176$

Jenkins, E. M., \& Mockaitis, A. I. (2010). You're from where? The influence of distance factors on New Zealand expatriates' cross-cultural adjustment. The International Journal of Human Resource Management, Volume: 21, Issue: 15, 2694-2715.

Kim, Y. (2008), Effects of expressive writing among bilinguals: Exploring psychological well-being and social behaviour. British Journal of Health Psychology, Volume 13, Pages 43-47

Koteswari, V. B. and Bhattacharya, M.S. (2007), Managing Expatriate Stress. Delhi Business 
Review, Volume 8, Number 1, Pages 89-98

Lee Hung-Wen and Liu Ching-Hsiang, (2007),An examination of factors affecting repatriates' turnover intentions. International Journal of Manpower, Vol. 28 Iss: 2 pp. 122 - 134

Luthans K.W., Farner, S. (2002), Expatriate development: the use of 360-degree feedback. Journal of Management Development, Vol. 21 Iss: 10 pp. 780 - 793

Luthans, F., \& Doh, J. P. (2009) International Management: Culture, Strategy, and Behavior 7th Ed., New York: McGraw-Hill

MacDonald S., Arthur N., (2005), Connecting career management to repatriation adjustment. Career Development International, Vol. 10 Iss: 2 pp. 145 - 159

Morgan L.O., Nie, W., Young, S.T., (2004) Operational factors as determinants of expatriate and repatriate success. International Journal of Operations \& Production Management, Vol. 24 Iss: 12, pp.1247 - 1268

MSQ short form (.pdf) (1977) extracted on 20.01.12, available at /www.psych.umn.edu NASSCOM (2012), India's Tech industry in the US - A Contribution Review, extracted on 30.05.12 available at www.nasscom.com

Naumann ,E. (1993),Organizational Predictors of Expatriate Job Satisfaction, Journal of International Business Studies, Vol. 24, No. 1, pp. 61-80

Olsen, Jesse E. And Martins, Luis L., (2009), The Effects of Expatriate Demographic Characteristics on Adjustment: A Social Identity Approach. Human Resource Management, Vol. 48, No. 2, Pp. 311- 328

Pate, J., Scullion.H. (2009), The changing nature of the traditional expatriate psychological contract. Employee Relations, Vol. 32 Iss: 1 pp. 56 - 73

Ronen, S. (1986), Comparative and Multinational Management, 4th edition New York, John Wiley and Sons.

Schuler RS, Dowling PJ, and DeCieri H (1993) An integrative framework of strategic international human resource management. Journal of Management 19(2): 419-59.

Selmer J., Chiu R.K., Shenkar O, (2007), Cultural distance asymmetry in expatriate adjustment . Cross Cultural Management: An International Journal, Vol. 14 Iss: 2 pp. 150 160

Suutari, V. (2003),Global managers: career orientation, career tracks, life-style implications, and career commitment. Journal of Managerial Psychology, Vol. 18 No. 3, pp. 185-207

Suutari, V., Brewster, C., (2001), Expatriate management practices and perceived relevance: Evidence from Finnish expatriates. Personnel Review, Volume 30, Number 5, and pp: 554-577.

Tahir, A.H.M., Ismail, M. (2007), Cross-Cultural Challenges and Adjustments of Expatriates: A Case Study in Malaysia. Turkish Journal of International Relations, Volume 6, Number: $3 \&$ 4, pg: 72-99.

Tornikoski, C. (2011), Fostering expatriate affective commitment: a total reward perspective. Cross Cultural Management: An International Journal, Vol. 18: 2 pp. 214 - 235

Tung, R., L. (1981), Selection and Training of Personnel for Overseas Assignments. Columbia Journal of World Business, Volume 16, Number. 1, pp-68-78.

Tung, R.L. (1987). Expatriate assignments: Enhancing success and minimising failure. Academy of Management Executive, Vol.1 (2), 117-126. 


\section{Macrothink

Webb, A. (1996), The expatriate experience: implications for career success. Career Development International, Vol. 1:5 pp. $38-44$

White, Darin W., Absher, Keith R. and Huggins, Kyle A. (2010), The Effects of Hardiness and Cultural Distance on Sociocultural Adaptation in an Expatriate Sales Manager Population, Journal of Personal Selling \& Sales Management, Vol. 31, No. 3, pp. 325-337

$\mathrm{Xu}$, Xiaofei. (2007), Inadequate training is a major reason that leads to expatriates' inadequate cross-cultural business communication competence. A case study with a China based company, Proceedings from the 7th Asia 6 Pacific Conference. The Association for Business Communication Date 27-31 March, 2007.available at http://businesscommunication.org/wp-content/uploads/2011/04/16ABCAsiaPac07.pdf Yavas U., Bodur M., (1999), Satisfaction among expatriate managers: correlates and consequences. Career Development International, Vol. 4: 5 pp. 261 - 269 